\title{
Hierarchies and Markets: The Defense Industry Under Stalin*
}

\author{
Mark Harrison** and Andrei Markevich***
}

Abstract. This paper summarizes the often bewildering organization of the supply of weapons and military goods in the Soviet economy, and the institutional channels through which demands on it were voiced and made effective. The general setting was one of a hierarchical command system. There were also relatively formalized marketlike structures within the system, which are distinguished from formal and informal outside markets. The most important of these internal markets organized the exchange of guns for rubles. Finally, there were overlapping systems of third-party regulation by an array of agencies responsible for planning, arbitration, audit, and state security.

The defense industry was one of the most important components of Stalin's military, economic, and political system. Its military significance is suggested by the fact that Soviet defense factories outproduced Germany in World War II and rivalled those of the United States for the next half century. Table 3.1 gives an idea of some bare numbers. These show, for example, that in the peacetime decade before World War II the Soviet aviation industry produced more than 4,000 aircraft per year. In wartime the rate went up to nearly 30,000 a year on average; it goes without saying that the metallic monoplanes that fought for the skies in the 1940s bore little comparison with the wood-and-canvas biplanes of the early 1930s.

<Table 3.1 here.>

The defense industry was of great economic significance. The industry itself is best imagined as a relatively small hub of large-scale, specialized assembly plants and research units surrounded by a wide periphery of part-time subcontractors that provided the defense industry hub with the more general-purpose materials, components, fuels and energy, and services that it needed while supporting the civilian economy as well.

* This paper appeared as a chapter in Guns and Rubles: The Defense Industry in the Stalinist State, pp. 50-77. Edited by Mark Harrison. New Haven, CT: Yale University Press. Yale-Hoover Series on Stalin, Stalinism, and the Cold War.

** Mail: Department of Economics, University of Warwick, Coventry CV4 7AL, UK. Email: mark.harrison@warwick.ac.uk.

*** Mail: The New Economic School, Suite 1721, Nakhimovskii Prospekt 47, 117418 Moscow, Russia. Email: amarkevich@cefir.ru. 
In 1938, for example, military orders accounted for just over 16 percent of the gross output of "civilian" engineering factories. ${ }^{1}$ The 1939 plan for production of shell parts designated no less than eighteen different civilian ministries as subcontractors. ${ }^{2}$ Specialized military factories naturally accounted for the bulk of supply of all military items; in 1940, for example, the figure was 78 percent (Simonov 1996: 154). But they also contributed significantly to the supply of civilian products: as late as 1938 about one fifth of their gross output still took the form of civilian items, and five years earlier the analogous figure had stood at more than one third. ${ }^{3}$

The interpenetration with the civilian economy makes the exact scope of the defense industry hard to define. The fuzziness was partly deliberate: the peripheral facilities were designed to swing over from civilian to war production in the event of war. The blurring of boundaries was also an inevitable product of rapid technological change: the pattern resulting when a radio wave rebounds from a solid object was a scientific curiosity in one decade and the object of a vast, secret, specialized industry in the next. As for orders of magnitude, a purely administrative definition of the industry gave the number of specialized defense factories in dozens in the 1920s, the low hundreds in the 1930s, and nearer to one thousand in the 1950s; the number of employees was more than a million before World War II, and many times that thereafter (Barber et al. 2000: 11).

The political significance of the defense industry is not easy to weigh up. In the Stalin era the leaders of the defense industry tended to be men, never women, of the second or third rank. As a dictator Stalin did not tolerate rivals; no one could be as important as him. Nonetheless, he gave close attention to his military advisers and their demands on industry. After his death the defense industry leaders became more important; Dmitrii Ustinov, Stalin's youthful minister of the armament industry in the 1940s, rose to become one of a handful of aging relicts that ruled Brezhnev's Politburo in the 1970s. This book is about the Stalin era, though; Stalin himself is never far from the center of our attention and even when off the stage he cast a long shadow across it.

Our subject is how the Soviet defense industry worked, and how well it worked. It is notable that in most countries the defense industry works badly. Defense contractors are notorious for cost overruns and kickbacks. Soldiers find that under combat conditions their products misfire, stall, or sink. Every army has its slang for equipment that is "u/s" (unserviceable)," "duff," or "kaput." By some standards the Soviet defense industry worked quite well; it kept up with technology and supplied the armed forces with large numbers of weapons that were ruggedly adapted to unsophisticated solders fighting under unsophisticated conditions.

${ }^{1}$ GARF, 8418/27/238: 27-36 (1938).

${ }^{2}$ GARF, 8418/23/345: 145 (Kaganovich to the Defence Committee, January 10, 1939).

${ }^{3}$ For the 1938 figure, covering the planned output of the ministry of the defense industry, see GARF, 8418/22/463: 5-7 (Defence Committee, February 20, 1938). In 1933 civilian items accounted for 36 percent of the output of the military factories under the ministry for heavy industry: GARF, 8418/8/9: 3-6 (Mezhlauk to Molotov, July 31, 1933). 
The results are particularly impressive if we remember that the Soviet Union was, relatively speaking, a poor country with limited industrial resources. The best estimates available suggest that in the late 1920s, on the eve of forced industrialization, Soviet GDP per head of the population was about one quarter of that in the United Kingdom and one fifth of the United States level; in the whole of Europe only a few neighboring countries to the south east were poorer (Maddison 2000). When Stalin said, in 1931: "we are fifty or a hundred years behind the advanced countries," he was thinking in round numbers that were not intended to be precise; we can see with hindsight, however, that this estimate was quite accurate (Harrison 1994: 255-56).

How did a relatively poor country achieve such results? This overview chapter presents a few basics of the organization of the defense industry in the context of Soviet political and economic institutions. Other chapters deal in more detail with the organization of particular activities including planning, mobilization, labor employment, and research. The institutional setting of the defense industry had a political dimension and a market dimension.

Politically the Soviet defense industry operated in a context of dictatorship. Stalin and his immediate subordinates micro-managed the resources and priorities of the industry to a high degree by issuing commands which were often called "plans"; for this reason the Soviet economy has been called both a "planned economy" and a "command system." The plans had legal force; wilful violation of them was a criminal offense.

Thus a well known legal text of the period (Pashukanis 1935/1980: 308) declared: "The plan is the law of the Soviet state. Fulfillment of the plan is the sacred obligation of every economic agency, of every manager, of every working person. The obligatory nature of acts of socialist planning (plan discipline) is supported by various sanctions, in particular by the threat of criminal repression." While only a small proportion of such violations reached the courts, there is no doubt of the importance of the plan in the lives of citizens in every workplace and neighborhood.

The defense industry also operated in a context of markets. At first sight it is not clear how markets could fit within a framework of dictatorship and a command economy. Markets are about decentralization and choice. Shall I take this job or that, and how hard should I work? Shall I spend my money on this item or that, or should I save it? A dictator's agent, in contrast, must carry out orders; she ought not to make choices, other than between obeying and being punished for disobedience. In this book we will distinguish between "real" markets that existed independently of the dictator's will and "quasi-markets" that the dictator deliberately created in order to solve his own allocation problems. Separate chapters of this book deal with quasimarkets for weapons and military inventions, and the real labor market where defense factories recruited their workers. The coexistence of the command system, real markets, and quasi-markets presents a fascinating problem in economics.

\section{Command and Obedience}

\section{An Army-Like Economy?}

From 1918 onwards the Soviet Union was a one-party state. The Bolshevik (later communist) party dominated the state through its structure, which paralleled the state in each department and at every level, and through its placemen, the nomenklatura, 
appointed to state posts from head of state and prime minister down through territorial and functional hierarchies to management personnel in enterprises. As a ruling party the communists carried on the conspiratorial traditions of their underground revolutionary past, in particular clandestine decision-making and the blind obedience of ordinary members to higher-level committees that were poorly controlled by infrequent elective conferences. Such rules were made for dictatorship and by 1929 Stalin had emerged as the dominant leader of the ruling party; by 1932 his authority had become nearly absolute. Thus, the party ruled the state, but Stalin ruled the party.

An army is a good analogy for Stalin's command system in the obvious sense and also in less obvious ways. The core principle of military discipline is that of vertical hierarchy: a commanding officer at a higher level passes an order down to the rankand-file, who obey and carry it out. The results depend on the quality of the orders and the quality of their execution. The quality of orders depends on good strategy, intelligence, and communications: an effective command must be purposeful, well informed about strategic requirements and resources available, and passed on without being distorted by Chinese whispers. In the context of the Soviet economy the strategy of the leaders, the quality of their information, and the difficulty of ensuring that the detailed plans received by enterprises corresponded with the grand overall perspectives for the economy as a whole are all well-known areas of research (for example Zaleski 1971, 1980).

The quality of compliance arises because in real armies a commander's orders, however sensible or well founded, are not always obeyed in the spirit of the command. Soldiers may obey perfunctorily or ignore the command altogether, provided no one is watching them when they are shirking. Unobserved, soldiers may take the initiative to sell off army property or go into business on their own account. Officers at intervening levels of command may also turn out to be brutal, venal, lazy, or incompetent to function satisfactorily in the eyes of its own high command an army requires a code of discipline, a system that tracks supplies and money, and a military police.

Finally, the quality of orders and the quality of compliance interact. Armies operate within a framework of international and domestic laws. In theory an order may be unlawful and in that case the soldier does not have to obey it and may even be obligated not to. This contradicts one of the chief requirements of an army: in a wide range of operational circumstances its success will depend on the instinctive or even blind obedience of the men; the chain of command cannot work well if those at lower levels are continually stopping to check their commanders' orders against a rule book. The Soviet command system was like an army that stood above society in the sense that Stalin's orders could override the law or were the law. By the same token Stalin did not allow his agents to shelter behind legal or constitutional restrictions when he demanded that they carry out his orders.

One consequence was that agents at lower levels might have to break the law to comply with a superior's command. For example, to fulfil a production quota, managers often had to go into illegal (but "real") markets or bribe suppliers to obtain the necessary supplies (Belova 2001). The inability of planners to meet all needs and account for all contingencies was an important reason why real markets persisted despite the command system. In turn this created a dilemma for superior officials: when they saw their subordinates violating the law, they might find it hard to tell whether the purpose of the law-breaking was to support the plan or subvert it. 


\section{The Economy's General Staff}

How was the command system organized? One aspect was vertical: principals at higher levels received information from agents at lower levels and used this to formulate their orders. This is shown in Figure 3.1, Panel (A). Another aspect was horizontal: the economy was too complex to be organized in a single firm, so it was compartmentalized into many branches of production, distribution, transport, and so on. Goods and services then had to be exchanged among the various branches, and these exchanges were coordinated from above. This is shown in Panel (B). An important feature of the horizontal relations in the command economy was that agents should only engage in those that had vertical authorization; unauthorized transactions could be defined as disloyal or corrupt and criminal. While agents did have a general authorization to buy or sell the "non-funded" commodities that fell outside the limits of the central plan at their own discretion, the fact is that virtually everything that entered or left the defense industry was "funded," leaving defense industry managers with little or no theoretical freedom of action.

<Figure 3.1 here.>

As dictator, Stalin was the principal who stood above all others. He ruled through an interlocking series of party and state committees. Most important was the party Politburo, supposedly no more than the executive agent of the party's large central committee but actually the handpicked group with which Stalin interacted most frequently, on whom he relied to keep him informed and to implement his decisions. The most famous names of the Stalinist era were there including Molotov, his prime minister and later foreign minister, who sold western Poland to Germany in 1939 in return for the Baltic region and a temporary peace; Voroshilov, an old soldier of the Civil War who became Stalin's defense minister; Ordzhonikidze, who ran industry for Stalin until his suicide in 1937; and Lazar Kaganovich, Stalin's deputy as party leader during much of the 1930s, whose brother Mikhail was an important official of the defense industry. Later additions included Andrei Zhdanov, who ran Leningrad and its big weapon factories; Lavrentii Beriia, chief of secret police and labor camps, who oversaw the development of new military technologies from radar to the atom bomb; Georgii Malenkov, who later took over the party apparatus and picked up an important role in the development of Soviet aerospace; Nikolai Voznesenskii, who ran the war economy; and Nikita Khrushchev, who would denounce Stalin after the latter's death.

As a principal who valued vertical obedience and truth-telling, and desired his agents only to engage in horizontal transactions that he had authorized, Stalin disliked it when his subordinates stood up for each other and favored those that were frank with him and did not cover for others. Thus he lost faith in Ordzhonikidze when the latter tried to protect his officials from the purges, and promoted Voznesenskii, whom the others disliked as the Boss's pet. Later, however, when Malenkov and Beriia caused Stalin to doubt Voznesenskii's loyalty, Stalin had him shot (Khlevniuk 1993; Gorlizki and Khlevnyuk 2004).

<Figure 3.2 here.>

In the field of defense economics the first formal link in the "transmission belt" from Stalin and the Politburo to the ministries was provided by a high-level 
subcommittee of the party, the government, or sometimes both jointly. The succession is shown in Figure 3.2: in the 1920s a defense commission of the Politburo, then of the Council for Labor and Defense (STO); from 1930 to 1937 a joint partygovernment Defense Commission, and from 1937 to World War II a government Defense Committee; while Stalin himself tended to be an "ordinary" member of these subcommittees, they were always chaired by someone close to him such as Molotov, Lazar Kaganovich, or Voznesenskii. In World War II everything was done directly from Stalin's war cabinet, the State Defense Committee. After the war things became less formal but the principle remained the same: a few people stood between Stalin and the government and processed his instructions in a small group before passing them on to the ministries.

\section{The Chain of Command}

Stalin's orders went via the government, called the Council of People's Commissars from 1917 and renamed the Council of Ministers in 1946, or directly to individual commissars. The People's Commissars were government ministers who ran not only the usual departments for home and foreign affairs, defense, finance, education, and so on but also a wide range of ministries for production and distribution. The production and distribution ministries were the result of a state-owned economy; these ministries exercised the ownership rights over the means of production and distribution on behalf of the state. At this general level there were no fundamental differences in the way the defense industry was owned and managed from that applied to civilian branches.

<Figure 3.3 here.>

The general pattern of organization of a Soviet ministry is shown in Figure 3.3. There were three main levels: at the bottom were the direct producers organized in state-owned enterprises. The enterprises were grouped in together in larger associations. In the 1920s these tended to be called "trusts" in the spirit of capitalist holding companies, and the trusts had names that conveyed the sense of what they produced, for example the "Gun and Arsenal Trust," or the "Military Chemicals Trust." Under Stalin the trusts lost even the fiction of operational independence that they had had in the 1920s and tended to be replaced by ministerial departments usually called "chief administrations." Finally, the heads of chief administrations reported directly to the minister, with whom they belonged to the ministerial "collegium" or council; the more important heads of administrations had the status of deputy ministers.

In practice the ministerial organization chart could be still more or less complex than that shown. Exceptionally large or important establishments could be kept under the personal supervision of the minister, by-passing the chief administration. At the other extreme particularly small-scale or otherwise negligible outfits could be lumped together into a "trust," and such trusts could be agglomerated into "associations" that reported to a chief administration. In practice, therefore, the number of links in the transmission belt from the minister to the firm could range from one for the biggest factories to three or four for the least in size. But the general trend of the 1930s, as we shall see, was in the direction of simpler, shallower hierarchies with fewer levels. 
Table 3.2 provides a snapshot of the structure of the defense industry in 1936 when the industry became important enough to have its own ministry for the first time. At this time it comprised 274 separate establishments organized in eleven chief administrations and trusts; later the chief administrations were numbered rather than given names. The factories were highly diverse, ranging from largescale mass production facilities for guns and ammunition to much smaller workshops where artisans crafted aircraft out of wood and canvas; there were also research and experimental facilities, firing ranges, training colleges, and so forth.

In the 1920s the ministerial structure was relatively simple: there was a single ministry for state-owned industry, grandly called the Supreme Council of the National Economy (VSNKh). Other ministries controlled foreign trade, transport, and the channeling of food from the countryside to the towns. With rapid industrialization under the five-year plans this simple structure soon became more complex. In 1930 the food industry was carved out of VSNKh; in 1932 what remained of VSNKh was split into separate ministries for the heavy and light industries. Further subdivisions came in the second half of the 1930s. In December 1936 a separate ministry was created for the defense industry; two years later, in January 1939, the defense industry was shared out among four new ministries for the aircraft, armament, ammunition, and shipbuilding industries. These ministries did not cover the whole of specialized war production, however. A ministry of engineering, hived off from heavy industry in 1937, continued to deal with things like armored vehicles and mortar armament. In September 1941, however, new ministries were set up to specialize in tank and mortar production for the duration of the war.

After the war, completely new industries were created for the new atomic, missile, and radar technologies. Long range ballistic missiles were absorbed by the ministry of armament, but atomic weapons and radar were managed by temporary high-level government commissions until after Stalin's death when they were handed over to new ministries of the radiotechnical industry and medium engineering. It was after World War II that the titles of some engineering ministries ceased to mean what they said: "medium engineering" meant uranium and plutonium processing, nuclear power and nuclear bombs; "transport engineering" meant armored vehicles; "agricultural engineering" included short-range missiles as well as tractors and combine harvesters.

<Figure 3.4 here. $>$

The growing complexity of the ministerial structure in the 1930s and 1940s is illustrated in Figure 3.4. Why did it get so complicated? There are two main explanations, both plausible and consistent with the evidence, so at the moment we cannot easily identify how to share the burden of explanation between them.

There is a simple economic argument: the ministerial structure became more complicated to match the growing complexity of the economy. There is a little more to it than this. Suppose the ministerial structure had stayed the same while the economy industrialized and diversified. With no change in the ministerial structure it would have been necessary to develop new subdivisions within the existing ministries. VSNKh, for example, was set up in January 1918 with just 14 internal divisions, called "chief administrations." By 1920, including "centers and sections," there were 74 of them (Carr 1966: 182n). A similar process can be seen at work a decade and a half later in the ministry of heavy industry. In April 1932, four months after its first formation, this ministry had 13 branch administrations; by 1938 these 
had grown to 34 in number, and this was despite the loss of a number of major branches to separate ministries. ${ }^{4}$

<Figure 3.5 here.>

The minister's problem is illustrated in Figure 3.5. In Panel (A) he must coordinate two chief administrations responsible for production, say, one for guns and one for ammunition. In Panel (B) there is increased complexity of production so two new chief administrations have been added, say, one for airframes and one for aeroengines; aircraft also need to be fitted with guns during manufacture and supplied with ammunition for operations. The number of chief administrations has grown to four. The scope of the ministry has doubled, but the problem of coordinating its component parts has quadrupled. In panel (C) the minister has solved the coordination problem by devolving production to four new subordinate administrations and devolving coordination to the chief administrations; one chief administration coordinates guns and ammunition and the other coordinates aircraft and aeroengines, leaving the minister to coordinate between the two.

Panel (C) looks like a possible solution. The main problem is that the chain of command from the minister to the producers has lengthened. More intervening links will blur his view of those below him and increase the scope for his subordinates to ignore or disobey orders. One solution to the chain-of-command problem is to break up the ministry; this is shown in Panel (D). Breaking up the ministry restores short chains of command. A consistent interpretation of the process of ministerial fragmentation shown in Figure 3.3, therefore, is that it accelerated when the authorities became particularly anxious about detailed control of subordinates. Supporting evidence is found in the fact that by the late 1930s ministerial hierarchies were typically much shallower than in the early 1930s, with no more than one or at most two levels intervening between the minister and the factory in place of three or even four in the earlier years.

If ministerial subdivision was a solution, however, it creates a new problem, or more strictly it shifts the old problem to a higher level (Crowfoot and Harrison 1990): who will coordinate the ministers? Growing ministerial fragmentation often gave greater weight to the coordinating bodies that stood above ministers. One response to the rapid subdivisions of the late 1930s, for example, was the expansion of the apparatus of the Sovnarkom Economic Council (Figure 3.2) in 1940 into six minicouncils, one of them for the defense industry, each charged with oversight of one of the major branches of the economy. Thus, reducing bureaucracy in the ministries tended to result in more bureaucracy above them.

There is also a political explanation of why the Soviet economy tended to see a growing number of smaller, more specialized ministries. This trend was not confined to the defense sector, although it may be argued that the defense sector saw it first. When the Soviet Union was constituted in 1923 there were 10 government ministers. By 1936 the number had risen to 18. Ministerial fragmentation pushed the number to 43 by 1941 and 59 during 1946 (Zaleski 1980: 20). The creation of new ministries had a multiplier effect on the number of middle-level posts, since every ministry required its complement of deputy ministers, heads of chief administrations, deputy heads, chief assistants, and so on. This was Stalin's "other" job creation program: "I need not

${ }^{4}$ 1934: RGAE, 7297/44/1: 116-117. 1938: RGAE, 7297/28/36: 1-2. 
mention," he reported in 1939, "that the division of organizations has made it possible to promote hundreds and thousands of new people to leading posts" (Stalin 1939/40: $650)$.

On this interpretation Stalin bought the loyalty of his subordinates by offering promotion in return. A problem was that the number of people whose loyalty he needed tended to exceed the number of existing posts available or becoming vacant. He solved this further problem by frequent purges combined with ministerial subdivisions that created new leading positions in great numbers; But purges and reorganizations were also costly. Valery Lazarev (2005) suggests that after Stalin's death the promotion mechanism tended to become unviable and threatened the command system with bankruptcy.

Finally, Stalin may have had a more cynical motive. Perhaps a command system with a few powerful ministers ceased to suit him, to the extent that it enabled those at the next level below him to accumulate too much power. Perhaps he considered that it made it too easy for a rival to emerge as a potential successor. In the early 1930s, for example, one man ran most of Soviet industry: Sergo Ordzhonikidze. As industry grew, so did his influence. Increasing the number of chief administrations under him simply added to the layers of middle-ranking officials who owed their positions and allegiance directly to Ordzhonikidze. In contrast, increasing the number of other ministers diluted Ordzhonikidze's influence, widened the circle of those who owed their loyalty to Stalin himself, and reduced the chances that another Ordzhonikidze would ever emerge. It took more than this to solve the problem of Ordzhonikidze himself, however: Stalin not only broke up his empire and destroyed those loyal to him, but also drove Ordzhonikidze to suicide (Khlevniuk 1993).

\section{The Quasi-Market for Military Goods}

Markets existed under Stalin's dictatorship for good reason. The markets were, strictly, of two kinds: real markets and quasi-markets. Quasi, from Latin, means, "as if it were"; a quasi-market is market-like yet lacks some of the essential properties of real markets. The differences are summarized in Table 3.3. Real markets were formed by buyers and sellers who were independent of each other. When agents of the state or state-owned enterprises bought or sold in real markets, for example, the other party was usually a private agent or at least a private intermediary. They entered the market independently because it was in their own self-interest to do so. Prices were set by interpersonal negotiation, impersonal bidding, or preset in the presence of market power. The interaction of supply and demand led to one of several possible equilibria, depending on the institutional arrangements in the market (Morishima 1984: 13-31). Contract disputes were resolved by custom or law. The market steered resources in the general direction of their most profitable use.

<Table 3.3 here.>

Quasi-markets, in contrast, were created by the state to allow its own agents to engage in decentralized transactions with each other. The agents entered the quasimarkets because they were told to. They were not supposed to behave in an independently self-interested way but to follow contingent rules. If they found themselves in dispute, the principal decided whether or not to intervene and whom to uphold. Prices and incentives in quasi-markets were formed by the principal's decision, not by an equilibrating process. The principal usually calibrated incentives 
in such as way as make his agents bring about a decentralized allocation of resources on lines already laid down in broad outline by centralized plans, only in more detail.

The terms "quasi-market" or "internal market" are widely used in the modern economic analysis of resource allocation within large private and public-sector organizations. Our present usage of the term, however, owes more to Ludwig von Mises who developed the idea of quasi-markets to describe what contemporary socialists like Oskar Lange wanted when they advocated market-like rules for bureaucratic socialist allocation. Mises regarded the idea of market socialism as inherently unworkable, likening it to a "triangular square." He argued that, since the agents would have no property of their own to lose, quasi-markets would be dominated by the "audacity, carelessness, and unreasonable optimism" of "the least scrupulous visionaries or scoundrels" (Mises 1949/1998: 705). We shall find that Mises had an element of prophetic truth of his side. At the same time the reality of quasi-markets in the Soviet defense sector was much more complex and interesting than this would suggest and the quasi-markets that Stalin created sometimes turned out to have a life of their own.

If we ask how markets came to be nested within the command system as a matter of historical fact, the answer conforms fairly well to the real versus quasi-market distinction. Quasi-markets were created deliberately within the command system, whereas real markets persisted and were tolerated or eventually recognized in spite of it. The Soviet command system was formed in two episodes, the Russian Revolution and Civil War of 1917 to 1921 and Stalin's "revolution from above" between 1929 and roughly 1934 (Davies 1994). The historical experience of these years shows us that the command system did not succeed in driving real markets out because it made too many mistakes and left too many needs unmet in the lower levels of society. Real markets persisted in the margins of the planned economy because, while carrying out their planned assignments, workers still had to go to the market to find bread and firewood, and managers still had to trade to get the fuel and materials they needed to fulfil the plan.

It is less obvious, at first sight, why much of the allocation of defense goods was delegated to quasi-markets. It is easy to see why Stalin's Politburo, meeting in the panelled offices of the Kremlin, should not know or care much about the provisioning of every household in every faraway provincial settlement. But the Red Army and the defense industry that supplied it were much more important to them than that. Stalin himself was obsessed with guns and their technical detail. Despite this, much of the real story of defense allocation can be summed up as follows: each year Stalin gave the Army a bag of rubles and told it to buy the guns it needed from Industry in a quasi-market. That is why this book is about Guns and Rubles.

<Figure 3.6 here.>

In Chapter 2 Andrei Sokolov introduced the two sides of the quasi-market for weapons as the Army and Industry. He noted that each is shorthand for a somewhat complicated and imprecise empirical counterpart. The Army stands for the defense ministry, but the latter term itself embraces a complex sequence of official designations, shown in Figure 3.6, for the ministerial departments that governed the Red Army and Navy. In this book we shall refer to all these as the "defense ministry" unless the context demands greater precision. Notably, Stalin himself occupied the post of defense minister from July 1941 to March 1947. The demand side of the quasi-market for weapons was constituted by the defense ministry's purchasing staff, 
charged with fulfilment of the annual plan of orders for weapons and military equipment. These held the purse of rubles that Stalin had set aside for them.

On the supply side, Industry represents the enterprises of the defense industry, organized under a ministry or, by the late 1930s, several ministries (shown above in Figure 3.4). They also had a plan to fulfil, but this was a plan for the overall value of gross output. In theory these two plans were supposed to be coordinated, but perfect coordination was impossible in practice and even limited reconciliation of military and economic plans proved to be costly and time-consuming. The result was a quasimarket, shown in Figure 3.7.

<Figure 3.7 here.>

When guns met rubles the result was not a real market of the sort imagined by Léon Walras (1874) who pioneered modern general equilibrium theory. In the Walrasian market masses of buyers and sellers interacted through an auctioneer who fine-tuned the prices of commodities to bring supply and demand into balance everywhere at once. In the Soviet quasi-market for weapons, hundreds of bilateral bargains took place in a chaotic sequence, one after another, as military officers visited factory managers and ministerial overseers to persuade Industry to produce what the Army wanted.

In reaching a bargain each side had strengths and weaknesses. The main advantage of Industry was its market position. Most major military items were produced in a handful of industrial enterprises, and there was little substitutability among them. On a detailed product classification most producers were effectively monopolists. The context, moreover, was not one of market equilibrium but of a shortage economy of generalized excess demand. This gave industrial producers the whip hand in negotiating terms with most buyers.

The strength of the Army was that it was not just any buyer. In the quasi-market for military goods it was almost entirely a monopsonist. It is true that in some periods the army and navy were organized under separate ministries with needs for armament and propulsive power that overlapped to some extent. It is also true that the NKVD, with its own internal security forces, was a third purchaser in the market, operating on a very small scale in comparison with the others. But there is no evidence in the documents that these three ever competed in the sense of bidding against each other for scarce goods or services. Thus, the relationship between buyer and seller in the quasi-market for military goods was almost always one of bilateral monopoly.

The Soviet Union's isolated position in the interwar global arena gave the Army very real strategic importance and ensured that Stalin would pay close attention to its needs. This was a source of both strength and weakness. Its strategic importance gave the Army the strength of high priority in the command economy; when funding or supplies were generally short, the Army would still get a large part of what it required. The weakness was that it made the Army a target for industrial suppliers who hoped to bargain away the Army's resources in their own favor. For example, its decisive role in the country's external security meant that the Army could not ultimately refuse to buy any weapons and end up without; it had to come to terms with Industry, and Industry worked to make these terms as advantageous as possible.

<Figure 3.8 here.> 
The spirit of the resulting bargain can be illustrated with the help of Figure 3.8. The Army's budget for weapons is a given purse of $V$ rubles. Given perfect coordination of the plans of Army and Industry, the gross output plan of the defense industry measured in rubles would also be equal to $V$. The Army expects to purchase a quantity of weapons $Q^{*}$ at the planned average unit price $P^{*}$ that would just use up its budget. Industry's problem is to take the Army's purse as easily as possible. To produce $Q^{*}$ costs a certain level of effort; Industry would gain if it could induce the Army to settle for fewer weapons at a higher price, say $Q^{\prime}<Q^{*}$ and $P^{\prime}=V / Q^{\prime}$. So Industry is tempted to push up the prices of weapons relative to the effort cost of producing them. For existing weapons, it might be able to do this by reporting costs that are inflated relative to the true effort of producing them; or by introducing new weapons and reporting higher costs relative to effort. A further possibility is that Industry could reduce effort by lowering the quality of output, since a quality reduction is equivalent to a price increase; Chapter 6 deals with this subject in detail. In other words, from Industry's point of view the Army's budget is a curve that happens to pass through the $P^{*} \times Q^{*}$ combination but, if Industry can report higher costs, and so move northwest along the curve to a more profitable combination than $P^{*} \times Q^{*}$, it will do so.

This vulnerability to exploitation by Industry left the Army in a weak position. There were two counterweights. First, the Army, like other consumers, found limited protection in the state arbitration courts that monitored the contracting process and tended to favor the buyer in their judgments (Kroll 1986, 1988). Second, the Army benefited from a unique system of direct monitoring of Industry that no other buyer was able to establish. It maintained a network of serving officers who acted as fulltime representatives of the Army's purchasing departments in the factories supplying defense. This limited the freedom of Industry to exploit the Army, but we will show that the defense suppliers had yet more cards up their sleeves in this asymmetric game.

Why did Stalin put up with the rivalries and tensions that permeated the quasimarket? There seem to have been two reasons. The first reason is that, however much he enjoyed the technical detail of weaponry, he could not carry out all the detailed allocation himself whether personally, or in his Politburo, or through his planners; the planners themselves did not want responsibility for this kind of work in case they ended up being blamed for the inevitable mistakes and failures (Belova and Gregory 2002).

Even if he did not want to do it himself, however, Stalin could have made the Army do it. The Army knew what it wanted; why not make the Army responsible for the defense industry? In terms of modern economics, if it was costly to transmit the information required to balance supply and demand across the market place, why not replace the quasi-market with a single vertically integrated firm? Here the second reason comes into play: Stalin probably did not want to encourage the emergence of a powerful, integrated military-industrial complex that could challenge his power (Harrison 2003). The competitive rivalries and tensions between Army and Industry suited him; he preferred to divide and rule.

\section{Third-Party Regulation}

Divide-and-rule is the stratagem of a ruler who mistrusts those around him, but it works by spreading mistrust widely through the institutions of governance. The functioning of the Soviet command economy reflected a low-trust environment in 
which everyone had to be told what to do because those above them did not trust them to do it without being told. Moreover, having told their subordinates what to do, government officials were rarely confident that it had been done. In fact, one of the key problems of the Soviet governance system turned out to be that everyone was willing to put some effort into pretending to do as they were told when they were really doing something else. One result was that officials at higher levels were rarely satisfied with their own observance of those below them, and resorted to third-party regulation to supplement their own monitoring systems.

The defense industry was subject to regulation by at least four types of external agency that reported directly to the government or the Politburo. These agencies dealt with planning and production accounting, contract arbitration, "control" or audit, and state security.

In traditional accounts of the Soviet command system the role of the planners has been much misunderstood. Rather than being all-powerful goal-setters and distributors of resources, they largely did as they were told. It was the political leaders who set the goals and distributed the resources, while the planners' task was to regulate and track the consequences. In doing this the planners, if anything, did as they were told more faithfully than most (Belova and Gregory 2002). One of their most important obligations was to tell the Politburo the truth about the state of the economy. To do this, side by side with their planning functions, they gathered information about the economy's stocks and flows. It is true that this information came largely from the producers, who themselves could not be trusted to tell the truth. If we express this problem in the terms of Figure 3.8, it was part of the planners' job to hold prices to $P^{*}$ so that the producers would have to fulfil their plan with $Q^{*}$ and not some lower level of output at a higher price. The planners did not succeed perfectly at this, but they did put limits on producers' discretion to put up prices and reduce effort or divert resources.

Centralized plans were fairly highly aggregated and did not prescribe the transactions between the Army and Industry in detail. The planners were not interested in regulating the countless petty disputes that arose over the detail itself. The detail of bilateral bargaining was handled through decentralized contracting procedures that were subject to oversight by the arbitration courts. According to Heidi Kroll $(1986,1988)$ the working of the decentralized contract system is best understood in terms of the need to economize on centralized planning costs, while the arbitration courts served to protect the buyer's "right to be served" in the context of seller's markets.

Given the importance of the defense industry and the secrecy surrounding it, contract disputes with regard to military items were not handled in the local arbitration courts. In the early 1930s they were centralized in a special joint arbitration commission of the armed forces and the defense industry under the ministry of the "workers' and peasants' inspection," a joint agency of the state and party. This ministry was dissolved in 1934 and the centralized resolution of contract disputes fell to the Soviet Union's chief arbitrator. At first he was committed to handle all disputes "regardless of value"; overwhelmed by a flood of trivial claims, he soon imposed a minimum value of 25,000 rubles on the claims that he would consider subsequently. ${ }^{5}$

${ }^{5}$ GARF, 5446/15a/1101: 1 (March 18, 1934); 5446/18a/893: 1 (December 16, 1936). 
The institutions of party and state "control" or audit carried out detailed investigations of enterprise management and local government more generally in order to detect the flouting of instructions, corruption, and other abuses. In the 1930s the control agencies comprised the ministry of the workers' and peasants' inspection and subsequently, from 1934, separate commissions for party and state control, the latter becoming a ministry of state control in 1940 (Ivkin 1999: 181-83). Both agencies had special representatives in every region whose remit included looking into wrong-doing in industry; some appointed special investigators to their staff for defense matters. ${ }^{6}$ At the end of 1937, however, the defense groups in both agencies were abolished, their powers passing to a new chief military inspectorate of the Defense Committee; the new chief inspector was granted an establishment of one secretary and nineteen subordinate inspectors for different branches of weaponry. ${ }^{7}$

In September 1940 the state control commission became a ministry once more and absorbed the Defense Committee's chief military inspectorate. Inspection of the defense industry became a much bigger and more specialized business. The new ministry organized inspection groups for each branch of the defense industry such as aviation, shipbuilding, and so forth. ${ }^{8}$

The most coercive form of third-party regulation involved intervention by the state security police: in the 1920s and early 1930s the unified chief political administration (OGPU), from 1934 the chief administration of state security of the interior ministry (NKVD, from 1946 the MVD), and from 1943 the ministry of state security (NKGB, from 1946 the MGB) (Ivkin 1999: 176-77). Further oversight of the economy was also provided by the economic administration of the NKVD-MVD (Petrov and Skorkin 1999: 21, 23). The security police could investigate, arrest, and punish cases of wrong doing that involved the suspicion of counter-revolutionary motivation or association. Such suspicions were easily aroused in anything involving military matters, specialized knowledge, or foreign technical collaboration from the time of the Shakhty affair in 1928.

In Stalin's Russia the security police acquired a close historical association with the high-technology branches of the defense industry. It seems likely that this was for several reasons. First, these were the branches where the Soviet Union lagged furthest behind its rivals; catching up was most urgent and required the greatest leaps of understanding and mastery of technique. Second, these branches rested on advanced scientific foundations where the relatively ill-educated political leaders were at the greatest disadvantage vis à vis the specialists. Third, because the science was relatively new, the Soviet Union had little choice but to select civilian specialists for their knowledge rather than their loyalty; the knowledge for which they were selected was crucially of scientific and technical developments abroad; this immediately made them potentially unreliable in an era when even "unconscious disloyalty" could be a crime (see Chapter 1). In short the progress of the defense industries was seen as vitally important, rested on science that politicians found difficult to evaluate, and

${ }^{6}$ In 1937 the state control commission (KSK) special representatives had positions for 23 such defense investigators, but only 7 were filled (GARF, 8418/12/402: 101).

${ }^{7}$ GARF, 8418/12/402: 6, 13, 14 (December 7, 1937).

${ }^{8}$ GARF, 8300/4/1: 1 (October 26, 1940). 
relied heavily on civilian specialists selected on criteria that made their allegiance doubtful. These naturally combined to attract the attention of the security services.

The tendency toward secret-police involvement in regulating military-related research is symbolized by the emergence of a strange and unprecedented phenomenon: the sharaga or prison design bureau. In the late 1920s the relationship between the industrial scientists and the regime underwent a crisis expressed in the levelling of wild accusations and criminal charges of economic sabotage and espionage against many engineers and economic specialists. First aircraft designers and then others were arrested and put to work on military projects as prisoners (Simonov 1996, Starkov 2000); the following information is drawn from work by Mikhail Morukov (2004). By the early 1930s the OGPU was employing more than four hundred imprisoned specialists in design bureaux located in Moscow, Leningrad, Khar'kov, and western Siberia. Of the total number on August 30, 1931, nearly half were working on defense projects ranging from new armored vehicles to submarines, artillery, explosives, and defenses against chemical agents. A second wave of arrests in 1937 and 1938 was associated with the Great Terror. Lavrentii Beriia, who took over the NKVD in the wake of the terror, set up a unified "special technical bureau" of the NKVD, answering directly to him, with 316 specialists organized in no less than eight sub-groups for various aspects of aviation, aeroengines, shipbuilding, propellants, explosives, armor steel, chemical agents and chemical defense.

During the war Beriia gained personal responsibility for the Soviet Union's nuclear weapon project (Holloway 1994; Simonov 1996). Finally, in October 1946 the NKVD added thousands of deported German military designers to its roster of imprisoned scientific personnel (Harrison 2000).

One reason that has been suggested for growing secret-police involvement in the defense industry is that the NKVD had a vested interest in monopolizing the development of military technologies. If so, this would have serious implications for our understanding of Stalin's dictatorship; it would mean that the NKVD became independently powerful of Stalin who was therefore not such an effective dictator after all. The evidence in favor of this idea is that the responsibilities of the NKVD grew remarkably through time. The evidence against it is that the NKVD seems to have been more interested in getting positive research results than in expanding its control of research assets. For example, engineers who achieved their assignments were often rewarded by early release.

Although it does not resolve the issue, it may help the reader to understand that a similar debate has unfolded around the NKVD and its control of forced labor. The forced labor system grew under Stalin and the NKVD controlled increasing numbers of forced laborers. Does this mean that the goal of the NKVD was to build an economic empire? Possibly. But there is also evidence that the NKVD planned to scale down forced labor more often than to expand it, that the arrests that recruited convicts for the labor camps were driven by Stalin more than by the NKVD itself, and that by the time of Stalin's death the NKVD (by that time MVD) leadership was convinced that widespread forced labor was damaging the Soviet economic and political system and social order (Gregory 2003b).

While the jury is still out on this issue, the role that the OGPU-NKVD-MVD will play in this book is to a large extent that of Stalin's loyal servant. The security police generally seems to have acted on Stalin's behalf and in his interest rather than following its own private agenda. 
To conclude, in the institutional setting of the command economy Soviet defense factories had to satisfy many masters. They had to keep happy their own ministerial bosses, the defense ministry as their main purchaser, and an array of third-party regulators who reported directly to the Boss: to Stalin himself. This apparatus was costly for the country to maintain. Was it worth it? One aim of this book is to evaluate the resources and mechanisms of the Soviet defense industry from various angles in relation to its goals. It is for the reader to evaluate our success.

The most important outcome of this chapter is to establish the concept of the quasi-market for weapons. When Industry produced guns for the Army, it did not do so by order, as the notion of a "command economy" might suggest. No matter how coherent and detailed was the procurement plan, it still had to be translated into contracts. The contracting process that exchanged guns for rubles was market-like. Being market-like is not the same as being a real market, and we address this through the concept of an internal or quasi-market. Well established in the regulation literature, this concept helps us to understand how a process that looks as if it should have been centralised to the extreme turned out to be dominated by informality and decentralization in its implementation. 
Figure 3.1. Vertical and Horizontal Relations

A. Vertical Relations

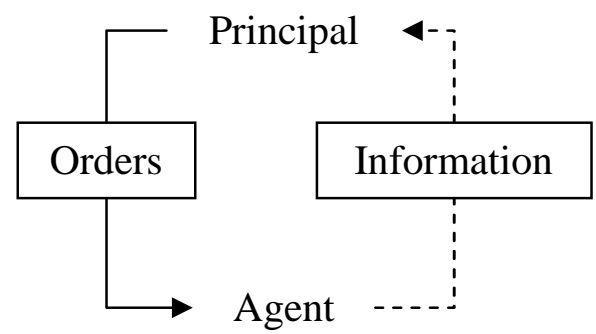

B. Horizontal Relations

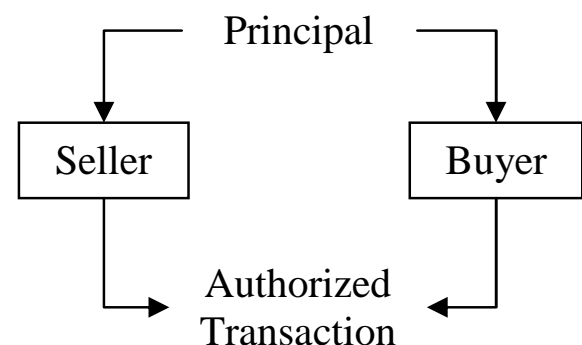


Figure 3.2. Stalin's Defense Subcommittee
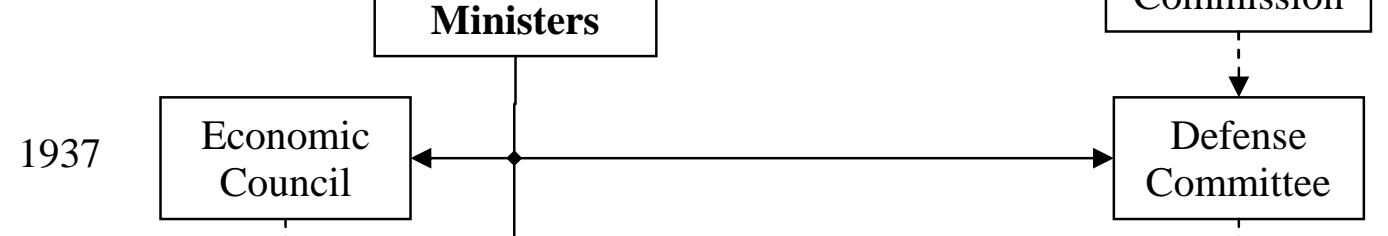

Sovnarkom:
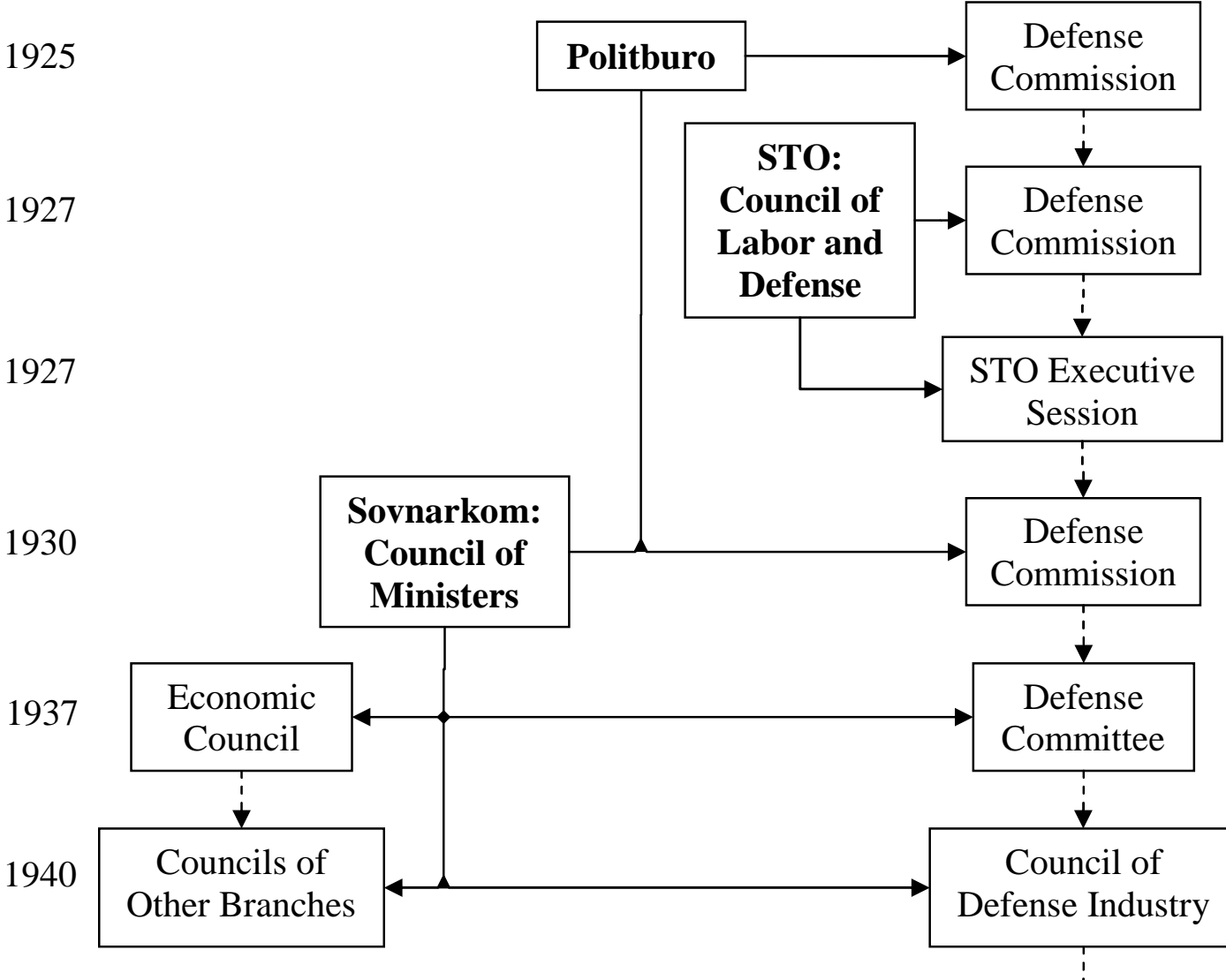

1941

$$
\text { Key: } \rightarrow-\rightarrow \text { Succession }
$$$$
\text { State Defense }
$$$$
\text { Committee }
$$ 
Figure 3.3. Minister, Chief Administration, and Enterprise

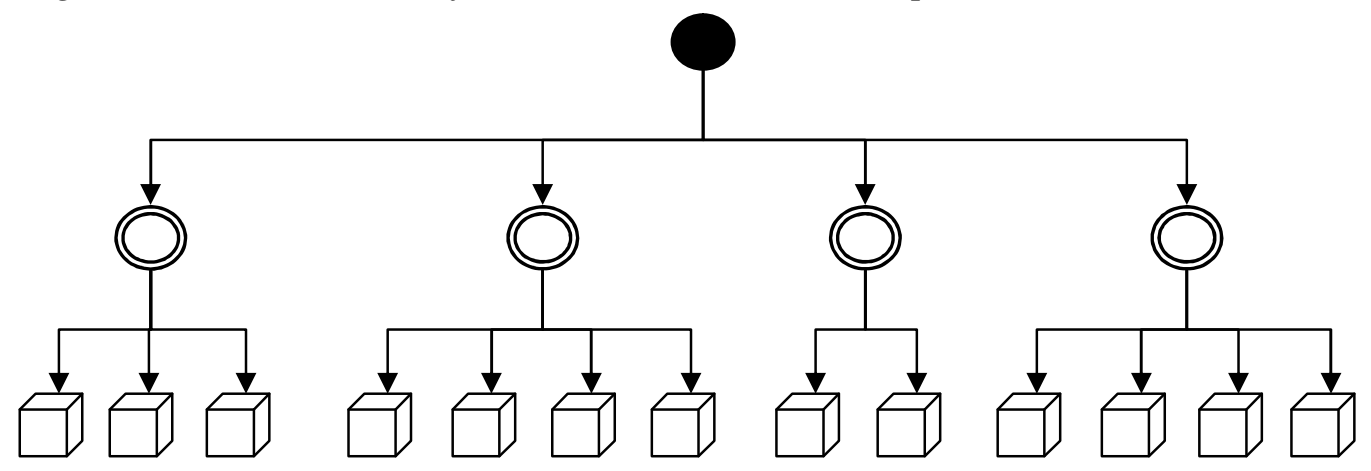

Key:

- Minister

(?) Chief Administration or Trust

曰 Enterprise 
Figure 3.4. The Ministerial Structure of the Soviet Defense Industry, 1917 to 1953

Dec. 1917

VSNKh: Ministry of Industry

Jan. 1932

Dec. 1936

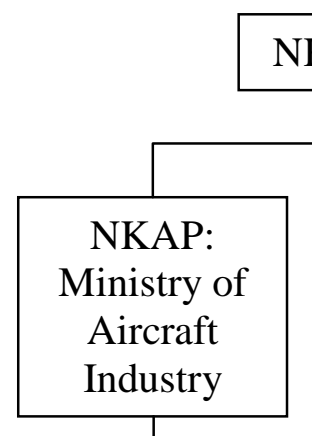

Sept. 1941

Jan. 1939

Nov. 1941

Oct. 1945

Jan. 1946

Mar. 1953

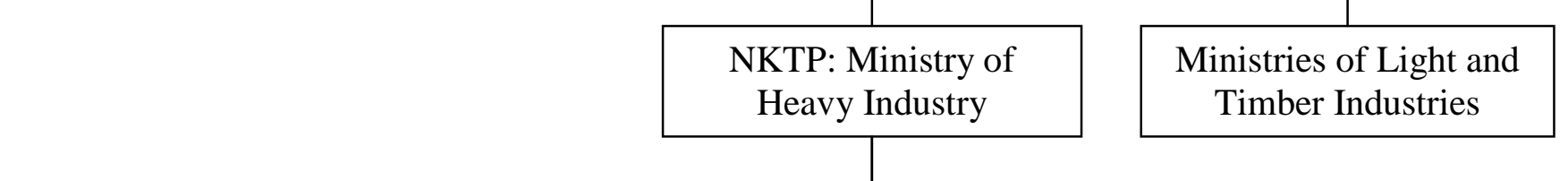

Ministries of Light and

Timber Industries

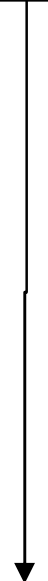

Source: Harrison (1985, pp. 278-9); Crowfoot and Harrison (1990, unpublished Appendix A). 
Figure 3.5. A Coordination Problem

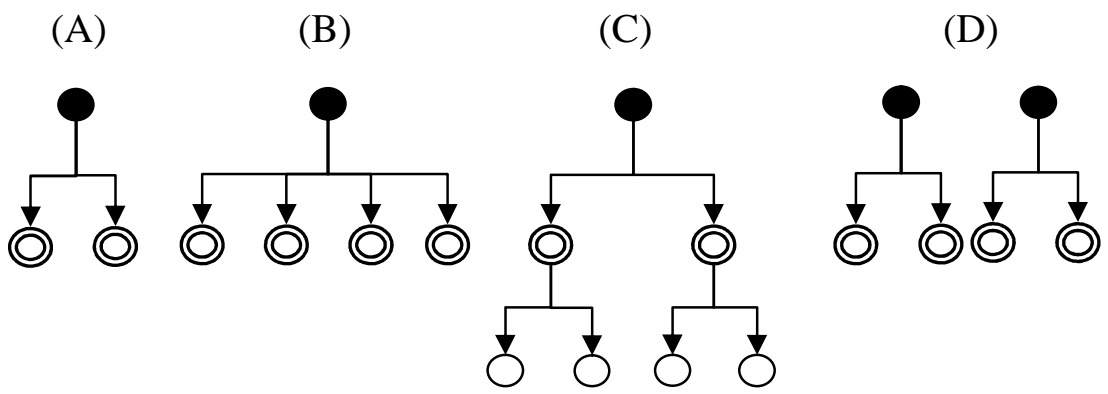

Key:

- Minister:

() Chief administration:

O Sub-administration: 
Figure 3.6. The Defense Ministry, 1923 to 1953

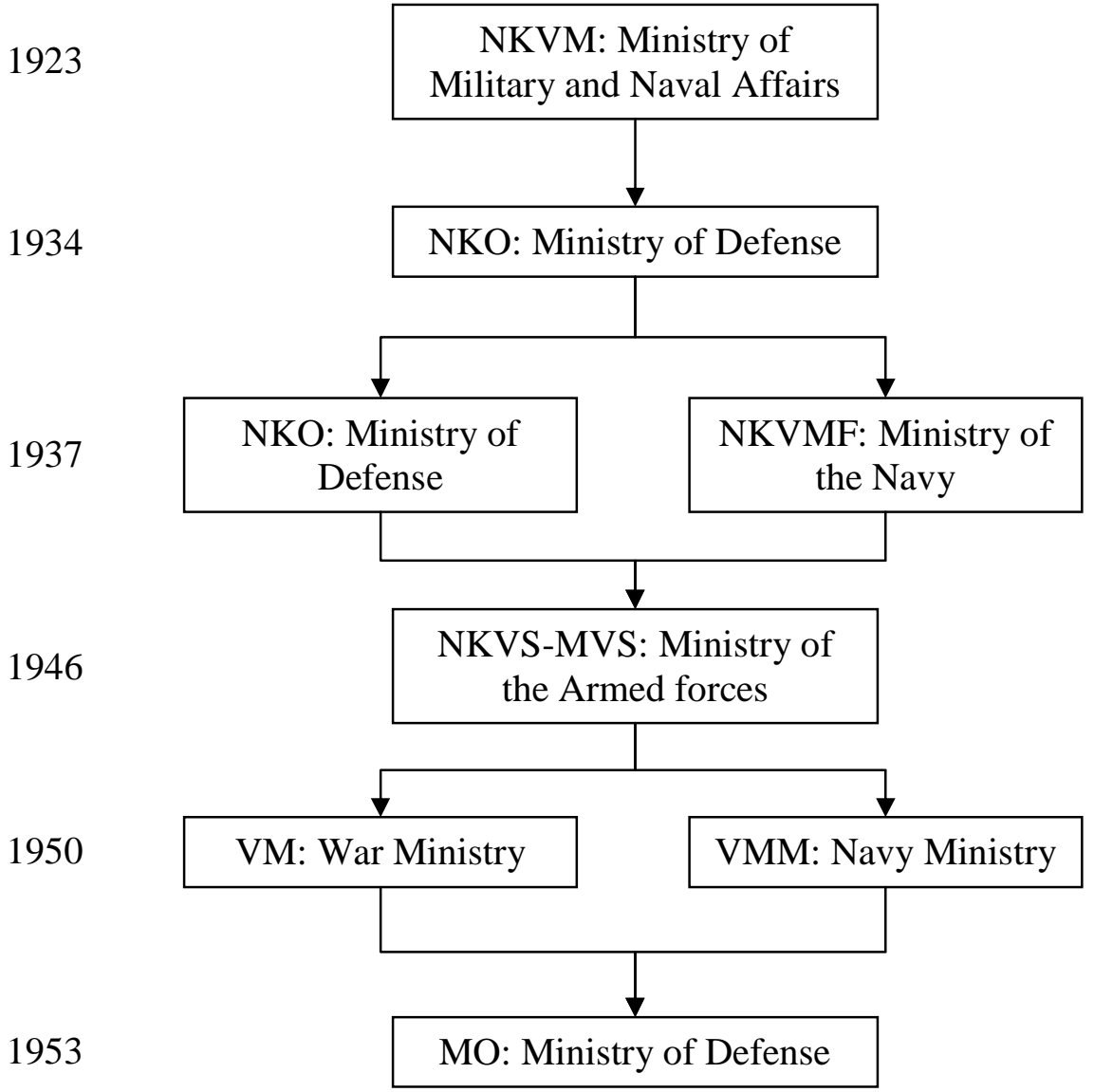

Source: Ivkin (1999, pp. 170-172). 
Figure 3.7. The Soviet Quasi-Market for Weapons

The Dictator: Stalin

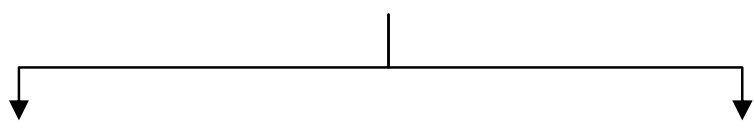

Army: the Defense Ministry supply staff and purchasing administrations for aircraft, artillery, ammunition, etc.

Demand: Plan of Military Orders for Weapons and Military Equipment
Industry: the Ministry for Heavy Industry, later Defense Industry and after that several more specialized ministries

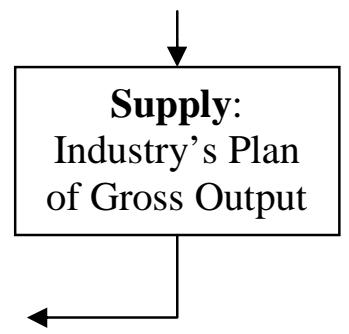

The Quasi-Market:

Quantity and Quality 
Figure 3.8. Supply and Demand for Weapons

Price

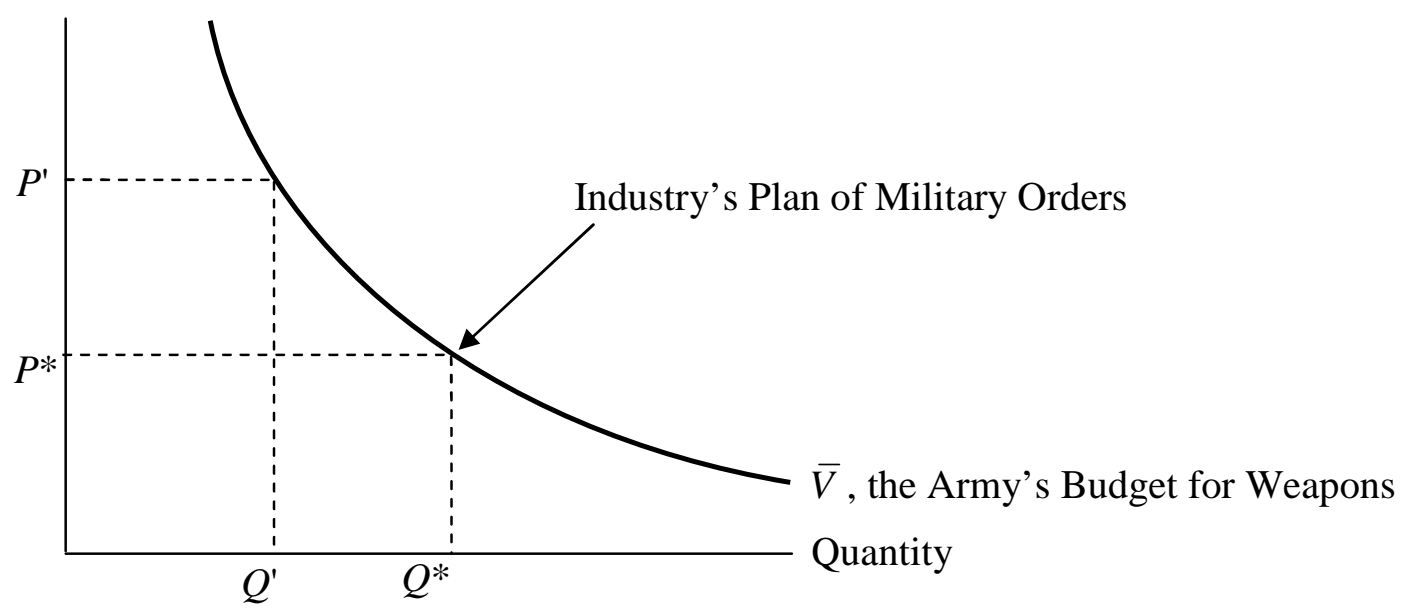

Note: For further reasoning underlying this figure see Gregory (2003a) and Harrison and Kim (2006). 
Table 3.1. Soviet War Production, 1930 to 1945, units

\begin{tabular}{lrr}
\hline & 1930 to 1940 & 1941 to 1945 \\
\hline Aircraft & 45,081 & 142,740 \\
Aeroengines & $79383^{\mathrm{a}}$ & 208,875 \\
Armoured combat vehicles & 28,487 & 106,888 \\
Artillery units & 72,129 & 497,685 \\
Mortars & 44,825 & 361,600 \\
Machine guns, thou. & 503 & 1,512 \\
Machine pistols, thou. & 103 & 2,135 \\
Rifles, thou. & 6,388 & 13,062 \\
Shells, thou. & 63,552 & 345,457 \\
Bombs, thou. & 14,365 & 49,859 \\
Mortar shells, thou. & 21,629 & 267,983 \\
Rifle cartridges, million & 10,442 & 13,880 \\
\hline a 1930 to 1938 only. & &
\end{tabular}

Sources: 1930 to 1940, Davies and Harrison (1997), except aeroengines from Kostyrchenko (1992, p. 429); 1941 to 1945, Harrison (1996). 
Table 3.2. The Ministry of Defense Industry, December 1936: 274 Establishments

1. Chief Administration of the Aircraft Industry (GUAP)

Total 69 establishments for aircraft and aeroengine production, research, design, and training, e.g. Factory no. 1 (the Aviakhim Factory); the Central Aero-Hydrodynamic Institute; the Rybinsk Aviation Technical School.

2. Chief Administration of War Industry (GUVP) Total 44 establishments for small-arms, artillery, torpedo, optical, and instrument production and design, e.g. the "Bolshevik" Factory; OKB-2 (the Shpital'nyi experimental design bureau).

3. Chief Administration of Ammunition (GUB) Total 55 establishments for shell, cartridge, explosive-tubing, and mine and bomb production, design, and testing, e.g. Factory no. 62; the Central Design Bureau; the Sofrino firing range.

4. Chief Naval Administration (Glavmorprom)

Total 23 establishments for shipbuilding and equipment production, research, design, and training, e.g. the Baltic Ordzhonikidze shipyard and TsKBS-2 (submarine design bureau) in Leningrad, and the Shipbuilding Institute and Shipbuilding Training School in Nikolaev.

5. Chief Administration of the Organic Chemicals Industry (Glavorgkhimprom) Total 10 establishments for production and experimentation, e.g. Factory no. 51; Central Research Laboratory no. 2.

6. Chief Administration of the Nitrate Industry (Glavazot) Total 13 establishments for production and research, e.g. Factory no. 40; the All-Union Chemical Research Institute.

7. Chief Administration of the Low-Power Electrical Circuit Industry (Glavesprom)

Total 28 establishments for telephone, radio, television, and electronic valve production, research, and training, e.g. the Red Dawn Telephone Factory, the All-Union Television Research Institute, the Radioelectronics Technical School.

8. All-Union Association of Factories of the Precision Industry (VOTI) Total 16 establishments for production, research, design, and training, e.g. the Aviapribor Factory for aviation instruments, the Research Institute for Automatic Equipment and Gyroscopy, the Special Design Bureau, and the Mechanics Training School in Vladimir.

9. All-Union Battery Trust

Total 12 establishments for production and experimentation, e.g. the Vossibelement Factory in Irkutsk; the Central Battery Laboratory.

10. All-Union Trust for Special-Purpose Steels (Spetsstal')

Total 3 production establishments, e.g. the Izhorsk factory.

11. Central Labour Institute (TsIT) Total 1 research establishment.

Source: RGAE, 7297/38/91, ff. 3-6 (December 21, 1936) 
Table 3.3. Real Markets and Quasi-Markets

\begin{tabular}{|c|c|c|}
\hline & Real Market & Quasi-Market \\
\hline Who forms the market? & Buyers and sellers. & Principal \\
\hline Who are buyer and seller? & Independent agents. & $\begin{array}{l}\text { Both subordinate agents } \\
\text { of same principal. }\end{array}$ \\
\hline What motivates them? & Self-interest. & Principal's command. \\
\hline Who enforces exchange? & Custom or law & Principal \\
\hline What forms prices? & $\begin{array}{l}\text { Buyer and seller } \\
\text { interact: supply and } \\
\text { demand reach an } \\
\text { equilibrium. }\end{array}$ & $\begin{array}{l}\text { Principal's decree tries } \\
\text { to align agents' self- } \\
\text { interest with principal's } \\
\text { by trial and error. }\end{array}$ \\
\hline What is role of market? & $\begin{array}{l}\text { Allocate resources to } \\
\text { most profitable use. }\end{array}$ & $\begin{array}{l}\text { Implement principal's } \\
\text { allocation plan in detail. }\end{array}$ \\
\hline
\end{tabular}




\section{Published References}

Barber, John, Mark Harrison, Nikolai Simonov, and Boris Starkov. 2000. "The Structure and Development of the Soviet Defence-Industry Complex." In The Soviet Defence-Industry Complex from Stalin to Khrushchev: 3-32. Edited by John Barber and Mark Harrison. London and Basingstoke: Macmillan.

Belova, Eugenia. 2001. "Economic Crime and Punishment." In Behind the Façade of Stalin's Command Economy: Evidence from the State and Party Archives: 131-58. Edited by Paul R. Gregory. Stanford, CA: Hoover Institution.

Belova, Eugenia, and Paul R. Gregory. 2002. "Dictator, Loyal and Opportunistic Agents: the Soviet Archives on Creating the Soviet Economic System." Public Choice 113(3-4): 265-86.

Bystrova, Irina. 2000. Voenno-promyshlennyi kompleks SSSR v gody kholodnoi voiny. (Vtoraia polovina 40-kh - nachalo 60-kh godov). Moscow: Institut Rossiiskoi istorii Rossiiskoi Akademii nauk.

Carr, E. H. 1966. A History of Soviet Russia, vol. 1: The Bolshevik Revolution, 1917-1923, part 2. Harmondsworth: Pelican.

Crowfoot, John, and Mark Harrison. 1990. "The USSR Council of Ministers under Late Stalinism, 1945-1954: Its Production Branch Composition and the Requirements of National Economy and Policy." Soviet Studies 42(1): 39-58.

Davies, R. W. 1994. "Changing Economic Systems: An Overview." In The Economic Transformation of the Soviet Union, 1913-1945: 1-23. Edited by R. W. Davies, Mark Harrison, and S. G. Wheatcroft. Cambridge: Cambridge University Press.

Davies, R. W., and Mark Harrison. 1997. "The Soviet Military-Economic Effort under the Second Five-Year Plan 1933-1937." Europe-Asia Studies 49(3): 369-406.

Gorlizki, Yoram, and Oleg Khlevnyuk [Khlevniuk]. 2004. Cold Peace: Stalin and the Soviet Ruling Circle, 1945-1953. New York: Oxford University Press.

Gregory, Paul R. 2003a. "Soviet Defence Puzzles: Archives, Strategy, and Underfulfillment." Europe-Asia Studies 55(6): 923-38.

Gregory, Paul R. 2003b. "An Introduction to the Economics of the Gulag." In The Economics of Forced Labor: The Soviet Gulag: 1-21. Edited by Paul R. Gregory and Valery Lazarev. Stanford, CA: Hoover Institution.

Harrison, Mark. 1985. Soviet Planning in Peace and War, 1938-1945. Cambridge: Cambridge University Press.

Harrison, Mark. 1994. "GDPs of the USSR and Eastern Europe: Towards an Interwar Comparison.” Europe-Asia Studies 46(2): 243-59.

Harrison, Mark. 1996. Accounting for War: Soviet Production, Employment, and the Defence Burden, 1940-1945. Cambridge: Cambridge University Press.

Harrison, Mark. 2000. "New Postwar Branches (1): Rocketry." In The Soviet Defence-Industry Complex from Stalin to Khrushchev: 118-49. Edited by John Barber and Mark Harrison. Basingstoke (England): Macmillan. 
Harrison, Mark. 2003. "Soviet Industry and the Red Army Under Stalin: A Military-Industrial Complex?" Les Cahiers du Monde russe 44(2-3): 323-42.

Harrison, Mark, and Byung-Yeon Kim. 2006. "Plans, Prices, and Corruption: The Soviet Firm Under Partial Centralization, 1930 to 1990." Journal of Economic History 66(1): 1-41.

Holloway, David. 1994. Stalin and the Bomb: the Soviet Union and Atomic Energy, 1939-1956. New Haven, CT: Yale University Press.

Ivkin, V. I., ed. 1999. Gosudarstvennaia vlast' SSSR. Vysshie organy vlasti i upravleniia i ikh rukovoditeli. 1923-1991 gg. Istoriko-biograficheskii spravochnik. Moscow: Rosspen.

Khlevniuk, Oleg V. 1993. Stalin i Ordzhonikidze: konflikty v Politburo v 30-e gody. Moscow: Rossiia molodaia.

Kostyrchenko, G. V. 1992. "Organizatsiia aviatsionnogo krupnoseriinogo proizvodstva." In Samoletostroenie v SSSR. 1917-1945 gg., vol. 1: 413-36. Edited by G. S. Biushgens. Moscow: TsAGI.

Kroll, Heidi. 1986. "Decentralization and Precontract Disputes in Soviet Industry." Soviet Economy 2(1): 51-71.

Kroll, Heidi. 1988. "The Role of Contracts in the Soviet Economy." Soviet Studies 40(3): 349-66.

Lazarev, Valery. 2005. "Economics of the One-Party State: Promotion Incentives and Support for the Soviet Regime." Comparative Economic Studies, 47(2): 346-63.

Maddison, Angus. 2000. The World Economy: A Millenial Perspective. Paris: OECD.

Markevich, Andrei. 2004. "Planning the Soviet Defense Industry: the Late 1920s and 1930s." PERSA Working Paper no. 37. University of Warwick, Department of Economics. URL: http://www.warwick.ac.uk/go/persa.

Mises, Ludwig von. 1949/1998. Human Action: A Treatise on Economics. Auburn, AL: Ludwig von Mises Institute.

Morishima, Michio. 1984. The Economics of Industrial Society. Cambridge: Cambridge University Press.

Morukov, Mikhail Iu. 2004. 'Deiatel'nost' khoziaistvennykh podrazdelenii OGPU-NKVD i oborona SSSR v 1929-1945 gg." Candidate of Historical Sciences Dissertation. Moscow.

Pashukanis, E. B. 1935/1980. "Course on Soviet Economic Law." In Pashukanis: Selected Writings on Marxism and Law: 302-45. Edited by Piers Beirne, Peter B. Maggs (transl.), and Robert Sharlet. London and New York: Academic.

Petrov, N. V., and K. V. Skorkin. 1999. Kto rukovodil NKVD. 1934-1941. Spravochnik. Moscow: Zven'ia.

Simonov N. S. 1996. Voenno-promyshlennyi kompleks SSSR v 1920-1950-e gody: tempy ekonomicheskogo rosta, struktura, organizatsiia proizvodstva $i$ upravlenie. Moscow: Rosspen.

Stalin, J. V. (1940). Leninism. London: Lawrence and Wishart.

Starkov, Boris. 2000. "The Security Organs and the Defence-Industry Complex." In The Soviet Defence-Industry Complex from Stalin to Khrushchev: 246-68. 
Edited by John Barber and Mark Harrison. Basingstoke (England): Macmillan.

Walras, Léon. 1874/1954. Elements of Pure Economics, or the Theory of Social Wealth. London: Allen and Unwin.

Zaleski, Eugène. 1971. Planning for Economic Growth in the Soviet Union, 19181932. Chapel Hill, NC: University of North Carolina Press.

Zaleski, Eugène. 1980. Stalinist Planning for Economic Growth 1933-1952. Chapel Hill, NC: University of North Carolina Press. 